\title{
Dynamics of nutrients and phytoplankton biomass in the Pearl River estuary and adjacent waters of Hong Kong during summer: preliminary evidence for phosphorus and silicon limitation
}

\author{
Kedong Yin ${ }^{1,2, *}$, Pei-Yuan Qian ${ }^{1,2}$, Jay C. Chen ${ }^{1}$, Dennis P. H. Hsieh ${ }^{2}$, \\ Paul J. Harrison ${ }^{3}$ \\ ${ }^{1}$ Center for Coastal and Atmospheric Research and ${ }^{2}$ Department of Biology, Hong Kong University of Science and \\ Technology, Clear Water Bay, Kowloon, Hong Kong, SAR \\ ${ }^{3}$ Oceanography, Department of Earth and Ocean Sciences, University of British Columbia, Vancouver, British Columbia, \\ V6T 1Z4, Canada
}

\begin{abstract}
The Pearl River in the south of China is the second largest river in China in terms of discharge volume. Two cruises were made to investigate the dynamics of nutrients and phytoplankton biomass in June and July 1998, across the Pearl River estuary to the adjacent territorial waters of Hong Kong. On-deck incubation experiments of 5 mixtures of freshwater from the surface with seawater from below the halocline were conducted to simulate time scales of phytoplankton blooms for each freshwater/seawater mixture and to examine uptake of nutrients. In July, phytoplankton growth rates increased with salinity of the mixtures, with the lowest growth rate $\left(0.81 \mathrm{~d}^{-1}\right)$ in fresh water and the highest $\left(2.41 \mathrm{~d}^{-1}\right)$ in $100 \%$ seawater (salinity $\left.=29\right) . \mathrm{PO}_{4}$ was lower in freshwater $(0.3 \mu \mathrm{M}$ ) than in seawater $(1.2 \mu \mathrm{M})$, whereas concentrations of $\mathrm{NO}_{3}+\mathrm{NH}_{4}+$ urea $(\sim 80 \mu \mathrm{M})$ and $\mathrm{SiO}_{4}(150 \mu \mathrm{M})$ were higher in freshwater than those in seawater ( $25 \mu \mathrm{M}$ for nitrogen and $26 \mu \mathrm{M}$ for $\mathrm{SiO}_{4}$ ). During the incubation $\mathrm{PO}_{4}$ disappeared first, indicating that $P$ was limiting the phytoplankton biomass. All mixtures reached the maximum in phytoplankton biomass in 3 to $4 \mathrm{~d}$. There was a regional maximum of phytoplankton biomass that occurred at the seaward edge of the estuarine plume during June. The region moved eastwards (away from the estuary) to the southern waters between Lantau Island and Hong Kong Island during July. Mixing diagrams of $\mathrm{NO}_{3}$ and $\mathrm{SiO}_{4}$ showed conservative behaviour with salinity in the estuary. These observations suggest that dilution by freshwater outflow was a controlling factor in determining the distribution of nutrients and phytoplankton biomass in the estuary due to high flow during June and July. The regional maximum of phytoplankton biomass was comparable to that resulting from the incubation and coincided with the exhaustion of $\mathrm{PO}_{4}$ during July. On the estuarine (west) side of the regional maximum, chl a fluorescence increased during $24 \mathrm{~h}$ incubations, but decreased at the station with the maximum and on the east side, suggesting the possible limitation of nutrients to the phytoplankton community. In the same eastern waters, both $\mathrm{PO}_{4}$ and $\mathrm{SiO}_{4}$ were very low. However, $\mathrm{NO}_{3}$ and $\mathrm{NH}_{4}$ remained abundant, suggesting possible co-limitation by phosphorus and silicon. We hypothesize that considerable seasonal rainfall in June and early July might have contributed an additional source of nitrogen to the water column, which resulted in the exhaustion of $\mathrm{PO}_{4}$ and $\mathrm{SiO}_{4}$ before nitrogen.
\end{abstract}

KEY WORDS: Nutrient dynamics - Salinity - Rain - P limitation - Phytoplankton blooms · Pearl River estuary · Hong Kong

\section{INTRODUCTION}

Temporal and spatial distribution in algal biomass and production in an estuary is regulated by the dilution of river flow, light, and mixing induced by tidal

•E-mail: kyin@ust.hk cycles and winds (Cloern 1996). River flow near the river mouth is usually too rapid to allow algal biomass to be accumulated. Dilution of the estuary due to river flow decreases down the estuary where the channel widens. As a result, suspended loads decrease and light penetration increases. Therefore, the region of algal blooms usually varies with river dis- 
charge. In the Mississippi River estuary, there is a 'downplume' progression of phytoplankton biomass and production maximum as the river discharge increases (Fox et al. 1987, Hitchcock \& Whitledge 1992). Uptake of $\mathrm{NO}_{3}$ and $\mathrm{NH}_{4}$ was also high at the chlorophyll a (chl a) maximum (Dortch \& Whitledge 1992). The input of Mississippi riverine nutrients was found to influence primary productivity in the shelf waters of the northern Gulf of Mexico (Lohrenz et al. 1997), and the reduced concentration of nutrients coincided with the region of peak chl a (Bode \& Dortch 1996). In the Yangtze River estuary, high standing stock of chl a (30 to $110 \mathrm{mg} \mathrm{m}^{-2}$ ) was observed in the plume of the Changjiang diluted water in the East China Sea (Gong et al. 1996). Examples of the regulation of regional phytoplankton blooms by river discharge can be found in many other estuaries; they include the Hudson River estuary (Malone 1977, Malone \& Chervin 1979), the Chesapeake Bay (Harding et al. 1986, Malone et al. 1988), the St. Lawrence River estuary and the Gulf of St. Lawrence (Sinclair 1978, Levasseur et al. 1984, Therriault \& Levasseur 1985, de Lafontaine et al. 1991). Similarly, the regulation of inorganic nutrients and phytoplankton blooms is found in different regions of San Francisco Bay (Cloern et al. 1985, Peterson et al. 1985). In the Strait of Georgia, mixing processes induced by maximal river discharge become important in regulating the supply of nutrients and phytoplankton production when nutrients in the Fraser River are low during late spring and summer (Yin et al. 1997a,b). An increase in phytoplankton biomass is correlated with an increase in salinity in the Po River and the Northern Adriatic Sea in Europe (Revelante \& Gilmartin 1976). The spatial and temporal distribution of phytoplankton biomass and productivity is important to production of organisms of higher trophic levels which, in turn, exert biological control on phytoplankton biomass and production (Chervin et al. 1981, Mackas \& Louttit 1988, Yin et al. $1996,1997 \mathrm{Cl}$.

The Pearl River estuary is situated on the south coast of China and connects to the northern part of the South China Sea. Hong Kong is part of its western shores. The Pearl River is the second largest river in China, after the Yangtze River, in terms of discharge. The Pearl River stretches for $2214 \mathrm{~km}$ and drains an area of $452000 \mathrm{~km}^{2}$ (Zhao 1990). It flows into the Pearl River estuary through 8 entrances, 4 of which enter the Ling Ding Yang estuary, a sub-estuary of the Pearl River estuary, between Hong Kong and Macao (Fig. 1). The annually averaged river discharge is $10524 \mathrm{~m}^{3} \mathrm{~s}^{-1}$, with $20 \%$ occurring during the dry season in October to March and $80 \%$ during the wet season in April to September (Zhao 1990). The coastal waters of Hong
Kong are profoundly influenced by 3 water regimes: the Pearl River discharge, oceanic waters from the South China Sea and coastal waters from the South China Coastal Current (Chau \& Abesser 1958, Chau \& Wong 1960, Williamson 1970, Watts 1971a,b, 1973, Morton \& Wu 1975). These water regimes are strongly subjected to 2 seasonal monsoons. In winter, the Northeast Monsoon prevails and the South China Coastal Current dominates the coastal waters of Hong Kong. In summer, the interaction of the estuarine plume and oceanic waters dominates due to the Southwest Monsoon. Therefore, the coastal waters of Hong Kong become very dynamic due to advection, mixing, and the interaction of freshwater from the Pearl River estuary, runoff and oceanic waters from oceanic currents.

In recent years, the Pearl River has received a high loading of anthropogenic nutrients from increased activities in agriculture (Neller \& Lam 1994), fish dike farming (Ruddle \& Zhong 1988) and sewage effluents (Hills et al. 1998) due to the population increase and economic development in southern China and the Pearl River delta region (Lin 1997). The increase in nutrients in the Pearl River has raised serious concerns over cross-border pollution in Hong Kong. Harmful algal blooms have become a common phenomenon in Hong Kong and have occured over 20 times every year in the last decade (EPD 1997). However, comparatively few harmful algal blooms have been reported in the Pearl River estuary. There is little information in the literature about the dynamics of nutrients and phytoplankton in the Pearl River estuary. This investigation is the first one to use an experimental approach to study the dynamics of nutrients and phytoplankton, in addition to a field investigation for the region.

In the present study, we conducted field incubation experiments in which freshwater was mixed with seawater obtained from below the halocline. Our idea was to simulate phytoplankton blooms in the mixture of freshwater and seawater during mixing due to entrainment and advection. The objectives were: (1) to examine effects of mixing ratios on phytoplankton growth rates, (2) to simulate time scales of algal blooms for different mixtures, and (3) to determine which is the first nutrient to limit algal biomass and production. During the same period, measurements of salinity, temperature, chl a and nutrients $\left(\mathrm{NO}_{3}, \mathrm{NH}_{4}\right.$, $\mathrm{PO}_{4}$ and $\mathrm{SiO}_{4}$ ) were taken in the estuary and the adjacent southern and eastern territorial waters of Hong Kong. Thus, the experiments provided explanations for possible biological processes which account for the spatial distribution of nutrients and algal biomass in the estuary and the coastal waters of Hong Kong. 


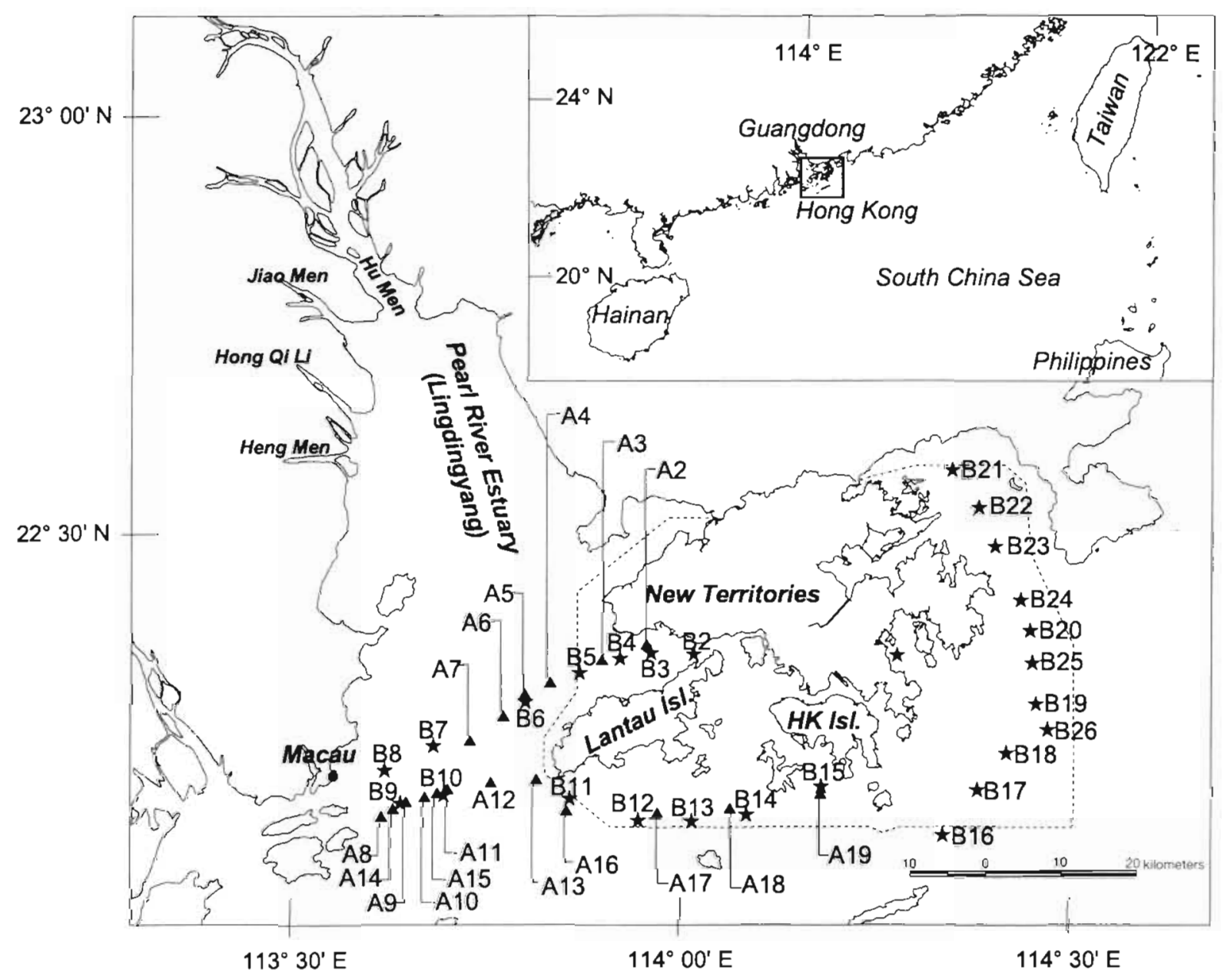

Fig. 1. Map of the Pearl River estuary and the sampling stations in the estuary and around Hong Kong territorial waters (marked by dashed line). Inset: location of the Pearl River estuary and Hong Kong along the south coast of China. Stations with A and B represent those sampled during the June and July cruises, 1998, respectively

\section{MATERIALS AND METHODS}

Sampling stations and samples. Two cruises were conducted during June 15 to 18 and July 6 to 10 , 1998, in the Pearl River estuary and the southern and eastern waters of Hong Kong. The sampling stations were selected along 2 transects, 1 across the Pearl River estuary between Hong Kong and Macao (Fig. 1), and the other from the estuary across the waters south and east of Hong Kong (Fig. 1). Water samples at the surface were taken with a plastic bucket. Salinity, temperature and fluorescence of the surface water samples were measured with an ATAGO hand refractometer, a thermometer and a Turner ${ }^{(B)}$ Designs fluorometer (Model 10), respectively. Subsamples for nutrients were taken with a $60 \mathrm{ml}$ syringe and filtered through pre-combusted $\left(460^{\circ} \mathrm{C}\right.$ for $4 \mathrm{~h}$ ), $25 \mathrm{~mm}$ GF/F filters mounted on Swinnexes into acid-cleaned Nalgen ${ }^{3}$ bottles. The filters were stored in aluminum foil for chl a analysis. The filters and bottles were placed on dry ice in a cooler and frozen immediately for laboratory analyses onshore. The samples were kept frozen until analysis which was carried out within a week.

Field incubation experiments. At 1 station, a surface sample was taken with the plastic bucket and a sample at $7 \mathrm{~m}$ below the halocline was taken with a submersible pump. The sampled station was $B 6$ for the mixing experiment in July. The surface and seawater samples were directly mixed at different ratios of surface to deep water: 100 to 0,75 to 25,50 to 50,25 to 75 and 0 to $100 \%$, which will be referred to as Mix 100/0, Mix75/25, Mix50/50, Mix25/75 and Mix0/100, respectively. The mixtures were transferred into $2 \mathrm{I}$ transparent glass bottles in duplicate, and were placed in a plastic box for incubation. The box was flushed frequently with surface water to keep the temperature similar to the surface seawater. The temperature of the 
incubator was monitored with a thermometer. Overheating was not a problem since air temperature was lower than the water temperature. During the $4 \mathrm{~d}$ incubation, water samples were taken twice a day, once in the morning and once in the evening. The fluorescence of samples was measured with the fluorometer on board ship. Other analyses for chl $a$ and mutrients $\left(\mathrm{NO}_{3}+\mathrm{NO}_{2}, \mathrm{NH}_{4}, \mathrm{PO}_{4}\right.$ and $\left.\mathrm{SiO}_{4}\right)$ were conducted later in the laboratory. The incubation was done with no neutral density screen for the June cruise and with 1 layer of neutral density screen for the July cruise. In the former case, phytoplankton might have experienced photoinhibition, and, therefore, the June experiment will only be referred to in text. One layer of neutral screen reduces light intensity by half, and is assumed to give saturating light intensities but not an inhibiting light intensity under bright sunlight. For $24 \mathrm{~h}$ incubations at other stations during the July cruise, subsamples were transferred into $50 \mathrm{ml}$ test culture tubes in triplicate and placed in the same incubation box covered with 1 layer of neutral density screen. Fluorescence of the samples in the test tubes was measured at the beginning and end of the incubation.

Analysis of chl $\mathbf{a}$ and nutrients. Chl a analysis was measured by in vitro fluorescence (Parsons et al. 1984). The samples were extracted with $90 \%$ acetone in darkness at $4^{\circ} \mathrm{C}$ for $24 \mathrm{~h}$. The fluorescence of the extraction was measured on a Hitachi ${ }^{\circledR}$ fluorescence spectrometer Nitrate (plus nitrite) and ammonium were determined manually following the procedures of Wood et al. (1967) and Slawyk \& Maclsaac (1972), respectively. Manual analyses of phosphate and silicate were based on the methods of Hager et al. (1968) and Armstrong et al. (1967).

\section{RESULTS}

\section{Mixing experiments}

\section{Phytoplankton growth rates}

In the incubation experiment conducted during the July cruise, the salinity of the mixtures was $0,6.5$, 14.5, 21.5 and 29, for Mix100/0, Mix75/25, Mix50/50, Mix25/75 and Mix0/100, respectively. Fluorescence in Mix 100/0 increased steadily over time, with the lowest phytoplankton growth rate of $0.81 \mathrm{~d}^{-1}$, while in Mix $0 / 100$ fluorescence showed a huge increase, with a growth rate of $2.41 \mathrm{~d}^{-1}$ after a time lag of $18 \mathrm{~h}$, and reached a plateau on Day 4 (Fig. 2). The time lag and following rapid growth indicated an acclimation to a shift in light from a low to a high regime. In Mix25/75, the increase in fluorescence was similar to that in Mix $0 / 100$ (growth rate $=$ $2.36 \mathrm{~d}^{-1}$ ). However, fluorescence at the end of the incu- bation was higher in Mix25/75 than in Mix0/100. In Mix75/25, fluorescence increased at $1.10 \mathrm{~d}^{-1}$, but started to decrease at $62 \mathrm{~h}$, the earliest time among all mixtures, and fluorescence never exceeded that in Mix100/0 (Fig. 2), suggesting possible salinity stress for the freshwater phytoplankton.

\section{Nutrients}

In the July experiment, initial $\mathrm{PO}_{4}$ concentrations were $0.25 \mu \mathrm{M}$ in Mix $100 / 0$ and $1.2 \mu \mathrm{M}$ in Mix0/100 (Fig. 3). $\mathrm{PO}_{4}$ decreased rapidly with time and disappeared after $56 \mathrm{~h}$ in all the mixtures except for Mix $0 / 100$ in which it disappeared after $62 \mathrm{~h}$, indicating $\mathrm{PO}_{4}$ limitation to phytoplankton growth and biomass. In contrast, $\mathrm{NO}_{3}$ concentrations were lower in Mix0/100 $(20 \mu \mathrm{M})$ than in Mix100/0 (62 $\mu \mathrm{M})$. In Mix25/75, $\mathrm{NO}_{3}$ disappeared after $80 \mathrm{~h}$, while in $\mathrm{Mix0} / 100, \mathrm{NO}_{3}$ disappeared $17 \mathrm{~h}$ earlier (after $62 \mathrm{~h}$ ). The disappearance of $\mathrm{NO}_{3}$ occurred before the exhaustion of $\mathrm{SiO}_{4} . \mathrm{NH}_{4}$ concentrations in Mix0/100. Mix75/25 and Mix50/50 varied during the incubation and were undetectable in $\mathrm{Mix0} / 100$ (Fig. 3). $\mathrm{SiO}_{4}$ concentrations remained saturating in all the other $4 \mathrm{mix}$ tures except for Mix0/100, which showed the exhaustion of $\mathrm{SiO}_{4}$ at $80 \mathrm{~h}$ (Fig. 3). The results of the June experiment were very similar to the July experiment.

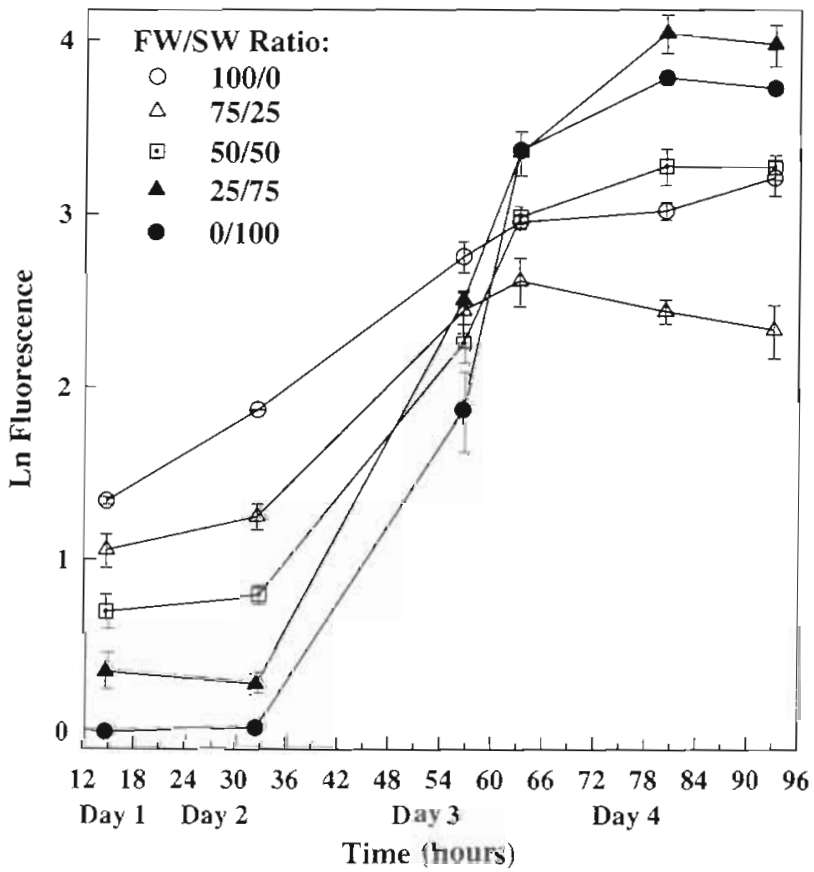

Fig. 2. Fluorescence versus time during the incubation of each mixture during the July cruise, 1998. Data plotted are the averages of duplicates and vertical bars are \pm 1 standard error (FW, freshwater; SW, seawater) 


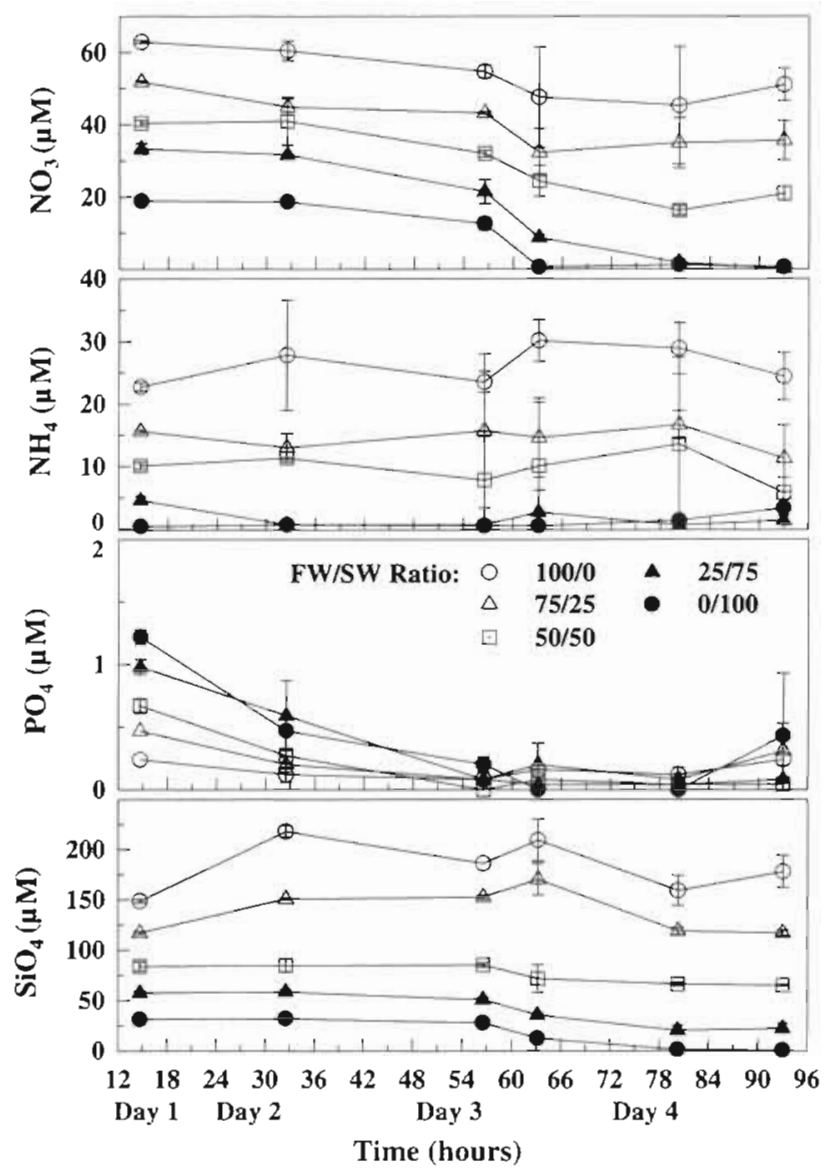

Fig. 3. Concentrations of nutrients versus time during the incubation of each of 5 mixtures of freshwater and seawater during the July cruise, 1998. Data plotted are averages of duplicates and vertical bars are \pm 1 standard error (FW, freshwater; SW, seawater)

$\mathrm{PO}_{4}$ decreased rapidly and was exhausted first among all the nutrients. $\mathrm{NO}_{3}$ disappeared only in $\mathrm{Mix} 0 / 100$ at the end of the incubation. None of the mixtures showed the depletion of $\mathrm{SiO}_{4}$.

\section{Distribution of chl $a$ and nutrients}

Salinity was low in the estuary and increased eastwards across the southern territorial waters of Hong Kong in June (Fig. 4) and July (Fig. 5), reaching the maximum salinity of $\sim 24$ at Stn A19 during June and Stn B15 during July, and being similar eastwards. Chl a biomass increased eastwards with the horizontal gradient and reached a maximum $\left(27 \mu \mathrm{g} \mathrm{l}^{-1}\right)$ at Stn A16, southwest of Lantau Island, in June (Fig. 4) and at Stn B14, between Lantau Island and Hong Kong Island, in July (Fig. 5). An on-deck, 24-h incubation showed that fluorescence increased during the incubation at stations on the estuarine side of Stn B14,

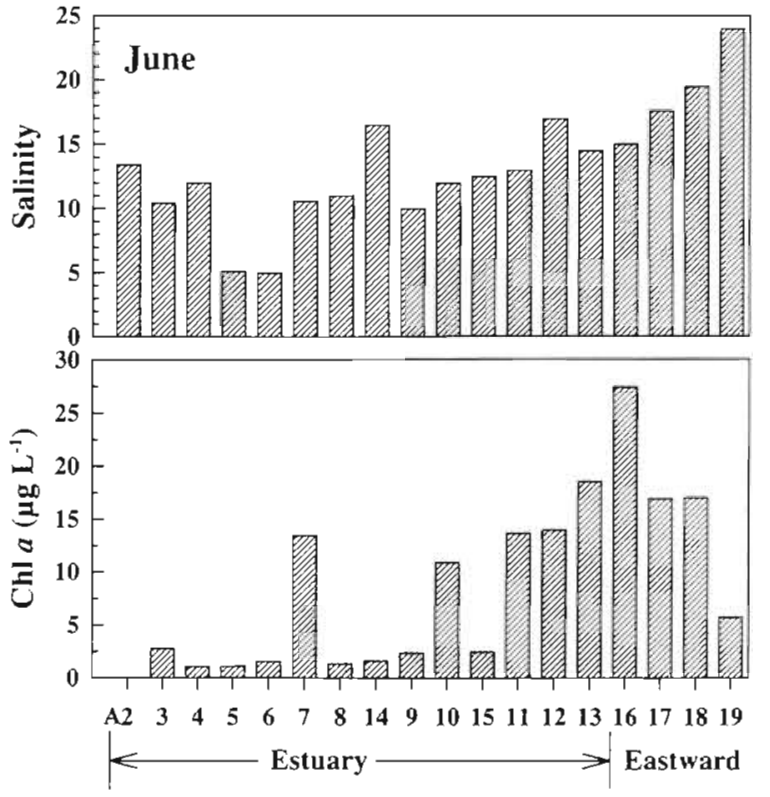

Fig. 4. Distribution of salinity and chl a at stations across the estuary to the waters south of Lantau Island during the June cruise, 1998. The chl a value was not available at A2

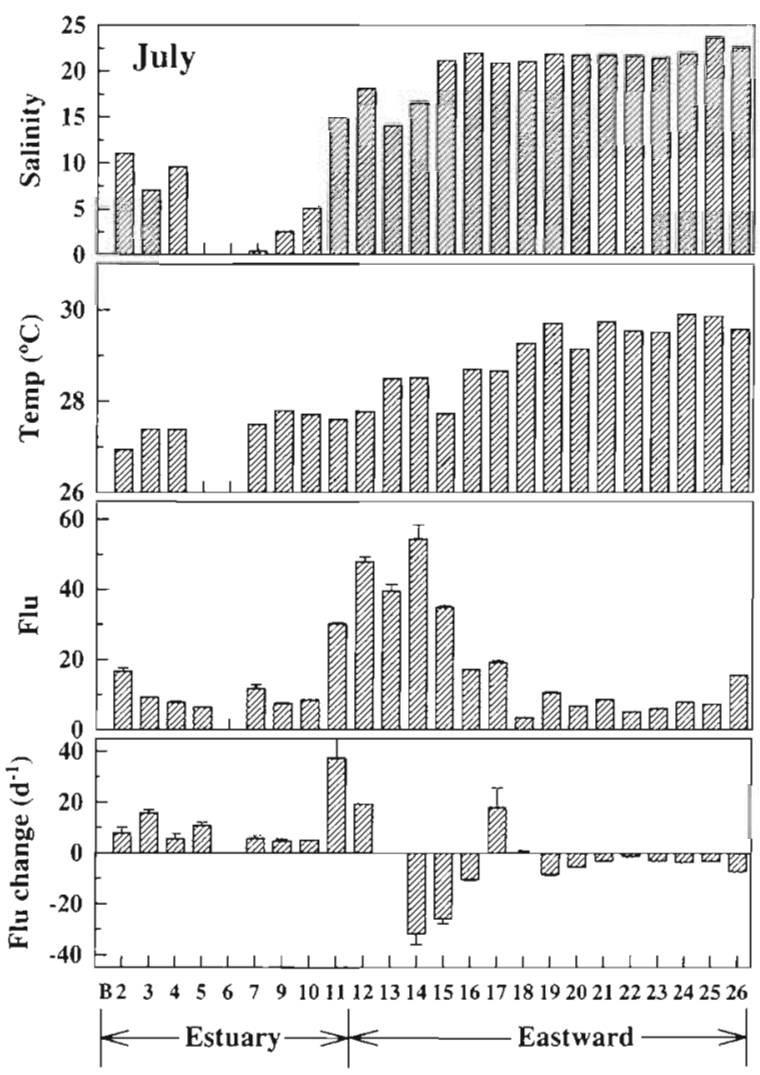

Fig. 5. Distribution of salinity, temperature, fluorescence and change in fluorescence during a $24 \mathrm{~h}$ incubation of samples at stations across the estuary to the southern and eastern territorial waters of Hong Kong during the July cruise, 1998. Data on salinity and temperature at Stns B5 and B6 and on fluorescence at Stn 6 were not available 


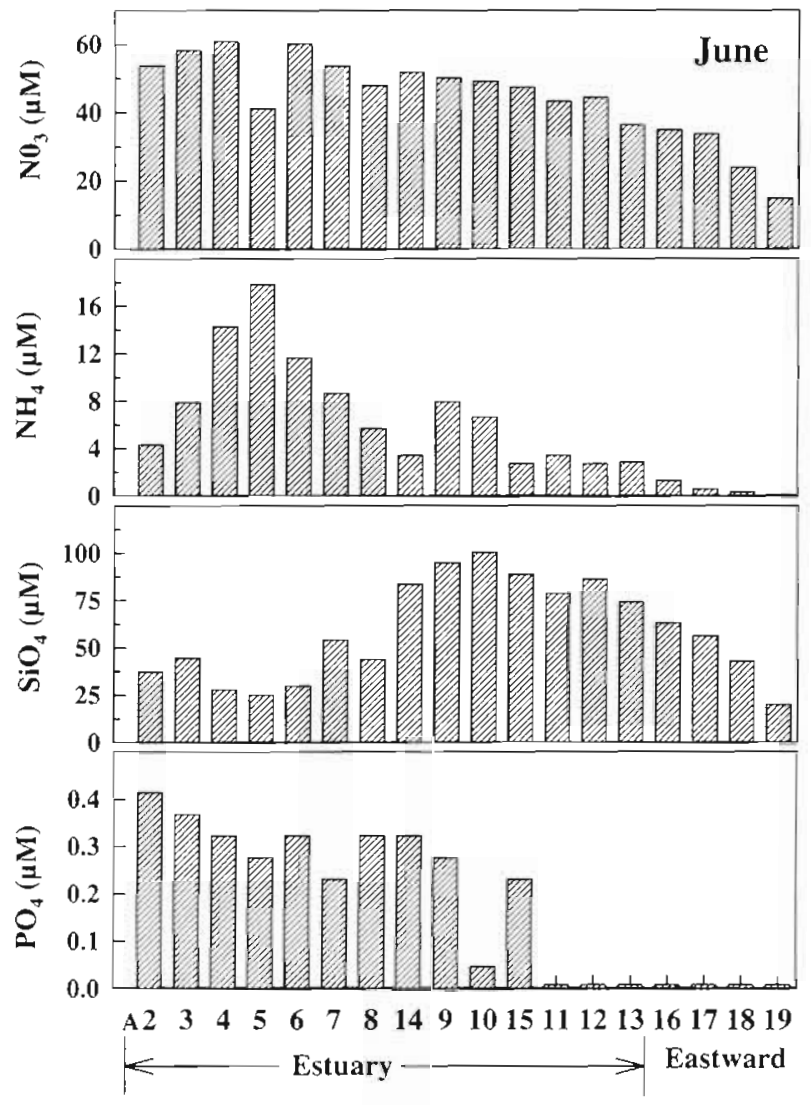

Fig. 6. Distribution of nutrients at stations across the estuary to the waters south of Lantau Island during the June cruise, 1998

but decreased at Stn B14 and other eastern stations except for B17 (Fig. 5). These results indicated that phytoplankton biomass increased downstream in the estuarine plume until a nutrient became limiting. Coincidentally, the maximum chl a concentration was $27 \mathrm{\mu g} \mathrm{l}^{-1}$ at Stn A16 (Fig. 4) and was similar to the maximum $\left(30 \mu \mathrm{g} \mathrm{I}^{-1}\right)$ obtained in Mix50/50 (salinity $=16$ ) and Mix25/75 (salinity $=22$ ) for the June experiment. The maximum in fluorescence at B14 (Fig. 5) was also very close to that obtained in Mix25/75 for the July experiment (Fig. 2). The similar biomass values between the incubated samples and stations suggested that the mixing experiments simulated the in situ processes of phytoplankton growth and there was little loss of phytoplankton biomass during the eastward movement of the estuarine plume.

$\mathrm{NO}_{3}$ concentrations were high $(60 \mu \mathrm{M})$ in the estuary and decreased eastwards during June and July, but $\mathrm{NO}_{3}$ always remained above $5 \mu \mathrm{M}$ (Figs. $6 \& 7$ ). $\mathrm{NH}_{4}$ concentrations were lower $(<25 \mu \mathrm{M})$ than $\mathrm{NO}_{3}$ and also decreased eastwards during June and July (Figs. 6 \& 7). However, $\mathrm{PO}_{4}$ showed depletion beiween A11 and A19 during June (Fig. 6) and be-

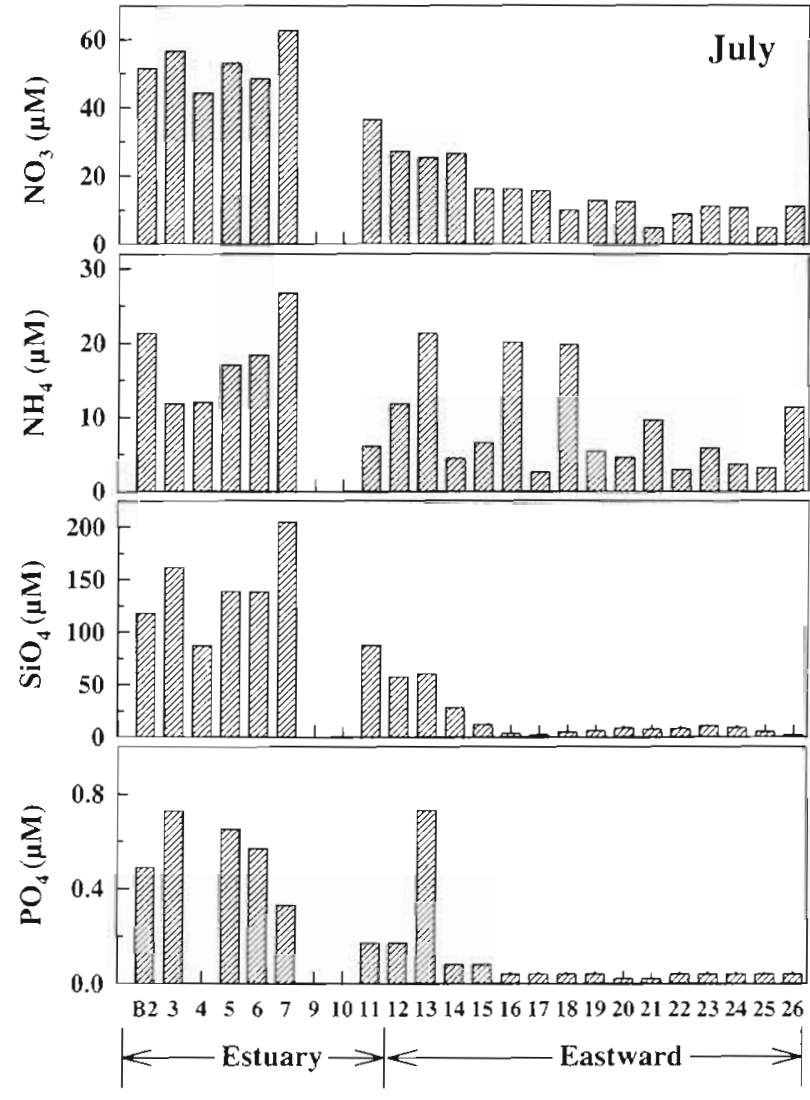

Fig. 7. Distribution of nutrients at stations across the estuary to the southern and eastern territorial waters of Hong Kong during the July cruise, 1998. No data were available at Stns 9 and 10

tween $\mathrm{B} 14$ and $\mathrm{B} 26$ during July (Fig. 7). $\mathrm{SiO}_{4}$ concentrations were higher ( $>75$ to $100 \mu \mathrm{M})$ at Stns $\mathrm{A} 9$ to 12 (including $\mathrm{A} 14$ and $\mathrm{A} 15$ ) than at other stations upstream and to the east $(<70 \mu \mathrm{M})$ during June (Fig 6). However, $\mathrm{SiO}_{4}$ became exhausted at $\mathrm{B} 16$ and eastwards during July (Fig. 7). The higher concentrations of $\mathrm{SiO}_{4}$ downstream in the estuary than upstream indicated the release of $\mathrm{SiO}_{4}$ during mixing. This was consistent with higher concentrations of $\mathrm{SiO}_{4}$ in the middle of the incubation of the mixtures Mix 50/50 in July (Fig. 3).

\section{DISCUSSION}

\section{Mixing experiments}

Phytoplankton species in the mixtures would grow in the mixtures according to their optimum range of salinity (Brand 1984, Rijstenbil 1987, 1988). In the experimental design of the present study, the mixing could produce combined effects of salinity stress, nutrient enrichment, dilution effects on grazing (Landry \& 


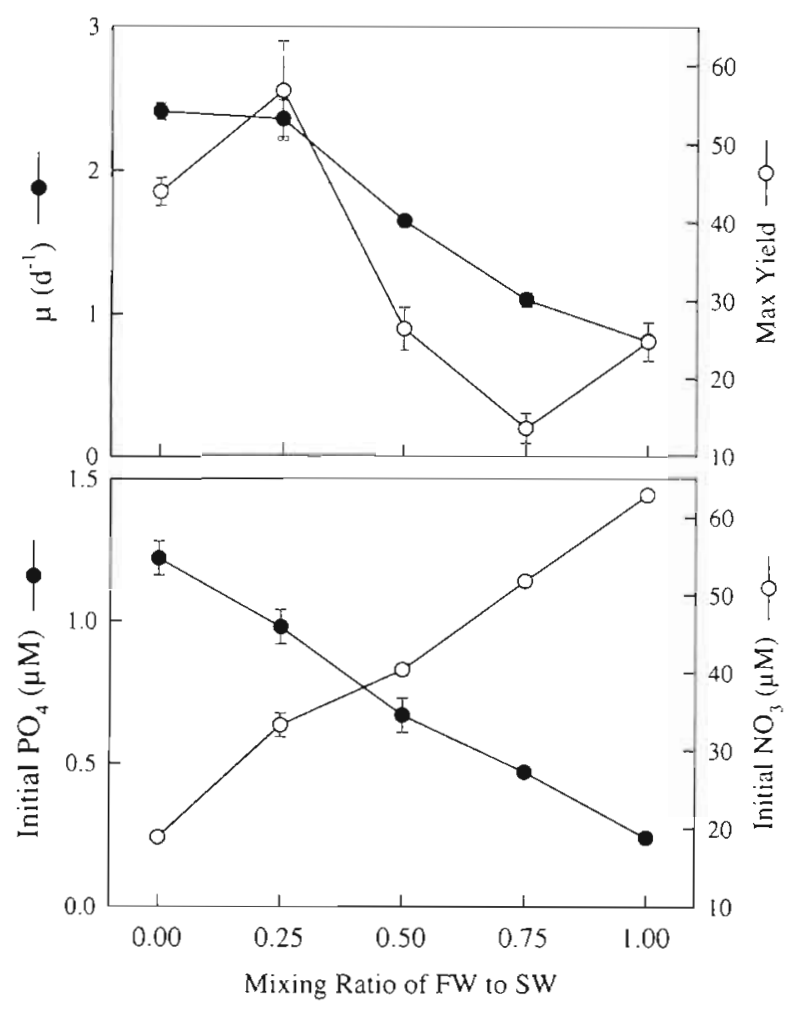

Fig. 8. Specific growth rate of phytoplankton $(\mu)$ versus mixing ratios for the July experiment. The values $1,0.75,0.5,0.25$ and 0 ( $x$-axis) correspond, respectively, with Mix 100/0 (freshwater), Mix 75/25, Mix50/50, Mix25/75 and Mixo/100 (seawater). Specific growth rates were estimated from the most significant regression of biomass increase versus time for each mixture in Fig. 2. 'Max yield' is maximum fluorescence for each mixture in Fig. 2

Hassett 1982), and an increase in light for deep seawater phytoplankton as well as some unknown effects (Kennish 1986). The increase in the maximal growth rate with salinity in July was significantly linear by omitting Mix0/100 ( $\mathrm{p}<0.001)$ (Fig. 8). This relationship clearly resembled the dilution effect on grazing shown in other studies (Landry \& Hassett 1982, Landry et al. 1995, Schlüter 1998). Microscopic examination showed numerous ciliates and colorless flagellates in the freshwater sample for the July experiment (Dickman pers. comm.). This agreed with other studies which showed that ciliates and heterotrophic flagellates were abundant in freshwater of up-estuary regions (Albright 1981, Painchaud \& Therriault 1989, Soto et al. 1993, Crump \& Baross 1996). Variable $\mathrm{NH}_{4}$ concentrations during the incubation of the freshwater-dominated mixtures (Fig. 3) might have reflected heterotrophic activity by grazing and bacterial decomposition. The lower biomass for Mix0/100 than Mix75/25 (Fig. 8) indicated that $\mathrm{NO}_{3}$ appeared to limit the final biomass of phytoplankton instead of $\mathrm{PO}_{4}$, which was higher in Mix0/100 than Mix25/75. On the other hand, it is likely that $\mathrm{PO}_{4}$ limited the final biomass in Mix25/75 and other mixtures since $\mathrm{PO}_{4}$ disappeared earlier than $\mathrm{NO}_{3}$ during the time course (Fig. 3). The notion of P-limitation was supported by the N/P ratio during the incubation. The N/P ratio of the initial concentrations was 15.5 in $\mathrm{Mix} 0 / 100$, and $>34$ in all the other mixtures in the July experiment, and N/P ratios were $>25$ in all mixtures in June (Table 1). N/P ratios increased after some hours of incubation (Table 1), clearly indicating $\mathrm{P}$-limitation in the mixtures, except for Mix0/100 for both June and July.

\section{Distribution of phytoplankton biomass and nutrients}

Entrainment between the river-discharged freshwater and the saline water below is a common vertical mixing process that brings phytoplankton upwards into the riverine and estuarine plumes (Mann \& Lazier 1991.

Table 1. Ratios of $\mathrm{N} / \mathrm{P}$ and $\mathrm{N} / \mathrm{Si}$ ( $\mathrm{N}$ including $\mathrm{NO}_{3}+\mathrm{NO}_{2}$, and $\mathrm{NH}_{4}$ ) during the incubation experiments with 5 ratios of freshwater and seawater mixtures in June and July, 1998. For N/P ratios only the sampling times T1 and T2 were selected because phosphate concentrations were too low to allow for reasonable calculations after T2. 'Mix 75/25' is, e.g., $75 \%$ freshwater and $25 \%$ seawater. Values in parentheses for July are $\pm \mathrm{SD}$

\begin{tabular}{|c|c|c|c|c|c|c|}
\hline \multirow[t]{2}{*}{ Date } & \multirow[t]{2}{*}{ Time } & \multirow[b]{2}{*}{ Mix $100 / 0$} & \multicolumn{3}{|c|}{ Freshwater and seawater mixtures } & \multirow[b]{2}{*}{$\operatorname{Mix} 0 / 100$} \\
\hline & & & $\operatorname{Mix} 75 / 25$ & $\operatorname{Mix} 50 / 50$ & $\mathrm{Mix} 25 / 75$ & \\
\hline & & & \multicolumn{3}{|c|}{ N/P ratios (by atoms) } & \\
\hline June 16 & $\mathrm{~T} 1=13.58 \mathrm{~h}$ & 223 & 166 & 143 & 156 & 25 \\
\hline June 17 & $\mathrm{~T} 2=32.5 \mathrm{~h}$ & 281 & 305 & 235 & 205 & 124 \\
\hline July 7 & $\mathrm{~T} 1=14.65 \mathrm{~h}$ & $364(4.5)$ & $143(1.0)$ & $76(4.34)$ & $39(4.4)$ & $16(1.2)$ \\
\hline \multirow[t]{2}{*}{ July 8} & $\mathrm{~T} 2=32.5 \mathrm{~h}$ & $856(455)$ & $310(111)$ & $192(15)$ & $62(30)$ & $41(3)$ \\
\hline & & & \multicolumn{3}{|c|}{$\mathrm{N} / \mathrm{Si}$ ratios (by atoms) } & \\
\hline June 16 & $\mathrm{~T} 1=13.58 \mathrm{~h}$ & 2.4 & 1.6 & 0.93 & 0.56 & 0.59 \\
\hline June 17 & $\mathrm{~T} 5=65.0 \mathrm{~h}$ & 0.58 & 0.59 & 0.43 & 0.35 & 0.25 \\
\hline July 7 & $\mathrm{~T} 1=14.65 \mathrm{~h}$ & $0.58(0.0)$ & $0.58(0.01)$ & $0.60(0.01)$ & $0.66(0.05)$ & $0.62(0.02)$ \\
\hline July 10 & $\mathrm{~T} 6=93.0 \mathrm{~h}$ & $0.42(0.01)$ & $0.40(0.01)$ & $0.41(0.06)$ & $0.07(0.05)$ & $0.09(0.05)$ \\
\hline
\end{tabular}


Yin et al. 1995a,b,c). The entrained phytoplankton serve as seed populations downstream and start to bloom when dilution rates are reduced and conditions of light penetration and salinity are improved (Yin et al. $1995 a, b, c)$.

The incubation experiments simulated the conditions phytoplankton may experience during mixing in the estuary in terms of time scales for blooms. The time scales for phytoplankton blooms in the Pearl River estuary were only 3 to $4 \mathrm{~d}$ after the mixtures reached a salinity of $\sim 15$. In the estuary, however, phytoplankton blooms were not found to occur along the transects between A.2-A8 in June and B2-B8 in July, since salinity was $<10$ in the estuary. Salinity-stressed growth and light-limited production were factors, but phytoplankton blooms should occur when given enough time. Therefore, this lack of blooms in the estuary indicates that dilution by freshwater discharge was the controlling factor in determining where phytoplankton blooms would occur during this time of the year, a period of maximal river discharge. The estuarine area (local name: Ling Ding Yang) from the river mouth (Hu Men) to Guishan Island (north to south) and between Hong Kong and Macau (east to west) (Fig. 1) is $2000 \mathrm{~km}^{2}$ (Zhao 1990). The river discharge averaged over several years from 4 river mouths (Hu Men, Jiao Men, Hong Li Qi and Heng Men) into Ling Ding Yang is $8.14 \times 10^{8}$ and $9.64 \times 10^{9} \mathrm{~m}^{3} \mathrm{~d}^{-1}$ for June and July, respectively, calculated from monthly data published by Zhao (1990). These rates equal 9427 and $11155 \mathrm{~m}^{3}$ $\mathrm{s}^{-1}$, respectively. Taking the top $2 \mathrm{~m}$ as the euphotic zone like a chemostat, an average dilution rate of the euphotic zone in the estuary would be 0.204 and $0.241 \mathrm{~d}^{-1}$ in June and July, respectively, which corresponds to residence times of 4.91 and $4.15 \mathrm{~d}$ in June and July, respectively. The yearly average Secchi depth is $\sim 1 \mathrm{~m}$ at stations near A6 (EPD 1994), which is a value common in many other estuaries. When reducing the euphotic zone to $1 \mathrm{~m}$, residence times become 2.46 and $2.08 \mathrm{~d}$ for June and July. Apparently, these dilution rates are too rapid to allow phytoplankton to accumulate in this section of the estuary during the period of maximal river discharge in June and July. As a result, phytoplankton blooms could only occur in the coastal region, beyond the land margins where dilution slows down greatly. Phytoplankton blooms occurred at A11 to A18 at the edge of the estuarine plume, where salinity was $>10$ to 20 in the waters south of Lantau Island in June and extended eastwards during July. The notion of dilution control was supported with mixing diagrams. Mixing diagrams of $\mathrm{NO}_{3}$ and $\mathrm{SiO}_{4}$ during July showed the conservative behaviour of these 2 nutrients until a salinity of $\sim 22\left(\mathrm{R}^{2}\right.$ is significant at $p<0.001$ for bath diagrams), whereas during June, the conservative behaviour held true for $\mathrm{NO}_{3}$ (Fig. 9).

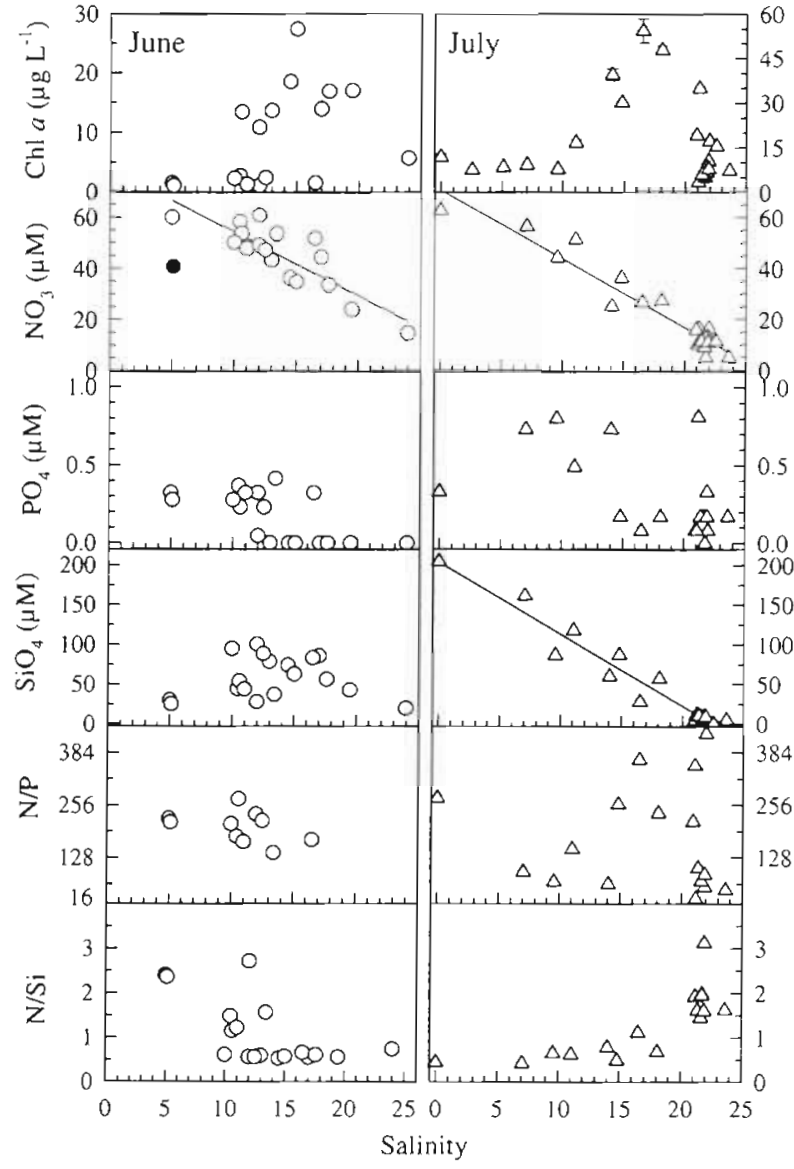

Fig. 9. Mixing diagrams of nutrients versus salinity for the June and July cruises. Value shown by solid circle in the $\mathrm{NO}_{3}$-salinity plot for June was omitted from the regression. Significance of the regression was based on $F$-value (Zar 1984)

Our results showed that in June and July the Pearl River estuarine plume swept eastwards through most of the southern territorial waters (B12 \& B18, Fig. 1). We observed that algal blooms did occur in these waters. High chl a concentrations are frequently found in the southern territorial waters during summer (Hong Kong Envirormental Protection Dept. unpubl. data). Non-harmful algal blooms (non-HABs) have not been followed in the HAB monitoring program of Hong Kong. Therefore, reports of lower HAB frequency in the vicinity of the Pearl River estuary than in the eastern region of Hong Kong should not mislead one to the notion that there are fewer algal blooms in the vicinity. Furthermore, HABs occuring outside of Hong Kong territorial waters were not monitored either

The spatial distribution of nutrients was consistent with that of phytoplankton biomass; nutrients decreased as phytoplankton biomass increased across the estuary east wards. Phosphorus was very low in the estuary on the eastern side of Stn A15 during June (Fig. 6) and Str B14 during July (Fig. 7) and appeared 
to be the limiting nutrient since nitrogen $\left(\mathrm{NO}_{3}\right.$ and $\mathrm{NH}_{4}$ ) was abundant. The P-limitation was consistent with $24 \mathrm{~h}$ incubation results (Fig. 5). P-limitation has also been observed in other large estuaries of China such as the Huanghe (the Yellow River) estuary (Chai et al. 1986, Turner et al. 1987, Hu et al. 1990), the Changjiang (Yangtze River) estuary (Edmond et al. 1985, Ning et al. 1988, Hu et al. 1990, Shen 1993), and along the Xiamen coast (Harrison et al, 1990).

The unique phenomenon during July was that relatively high concentrations of both $\mathrm{NO}_{3}$ and $\mathrm{NH}_{4}$ remained at the surface in the waters south of Hong Kong Island and in the eastern territorial waters, versus low concentrations of $\mathrm{PO}_{4}$ and $\mathrm{SiO}_{4}(\mathrm{~B} 16$ to $\mathrm{B} 26$, Fig. 7). N/Si was $<1$ after the salinity exceeded 15 during June, but during July, N/Si was $>1$ after the salinity reached 20 (Fig. 9). Therefore, additional nitrogen input was required to consume $\mathrm{SiO}_{4}$ to exhaustion in July if these waters were of predominantly estuarine origin. The spatial homogeneity of salinity (between 21 and 22) across the entire eastern territorial waters during July (B16 to B26, Fig. 5) indicated that this water body was not from the estuarine plume which usually has horizontal salinity gradients. The examination of precipitation records revealed that rainfall reached $970 \mathrm{~mm}$ during June 1 to July 6, 1998 (Hong Kong Observatory 1998). Therefore, we hypothesize that rainfall contributed additional nitrogen to the water column. Atmospheric inputs have been demonstrated to be an important source of nutrients for other regions, including the east coast of the USA (Paerl et al. 1990, Mallin et al. 1993), the French Atlantic coast (Collos et al. 1989), and the Strait of Georgia on the west coast of Canada (Yin unpubl. data). Nutrients in rainwater are usually richer in nitrogen than phosphorus or silicate (Paerl et al. 1990, Yin unpubl. data). Thus, the nitrogen input originating from rain seemed to drive the waters south of Hong Kong Island and the eastern territorial waters of Hong Kong to P-limitation and exhaustion of $\mathrm{SiO}_{4}$. Consequently, P-limitation resulted in unused $\mathrm{NO}_{3}$ and $\mathrm{NH}_{4}$ remaining in the water column. P-limitation and Si-exhaustion might lead to shifts in phytoplankton species composition to dominance by dinoflagellates or other non-silica-requiring species.

Acknowledgements. We are grateful to Dr Dana Kester who coordinated the cruises and accommodated our experiments on the ship. Financial support for the cruises was provided by the Croucher Foundation via a grant awarded to Dr Gary Heinke. We thank Tang Wing Yee Venus for assistance in the analysis of nutrients and Michelle Legault for proof-reading and technical assistance in mapping. Partial funding for this research was provided by the Pearl River Estuary Pollution Project funded by the Hong Kong Jockey Club and the ocean 863 project (818-09-01) sponsored by China National Science Foundation. We thank 4 anonymous referees who gave very useful suggestions and comments.

\section{LITERATURE CITED}

Albright LJ (1981) Heterotrophic bacterial biomass, activities, and productivities within the Fraser River plume. Can J Fish Aquat Sci 40 (Suppl 1):216-220

Armstrong FAJ, Stearns CR, Strickland JDH (1967) The measurement of upwelling and subsequent biological processes by means of the Technicon AutoAnalyzer and associated equipment. Deep-Sea Res 14:381-389

Bode A, Dortch Q (1996) Uptake and regeneration of inorganic nitrogen in coastal waters influenced by the Mississippi River: spatial and seasonal variations. J Plankton Res 18:2251-2268

Brand LE (1984) The salinity tolerance of forty-six marine phytoplankton isolates. Estuar Coast Shelf Sci 18:543-556

Chai X (1986) Comprehensive survey and research report on the water areas adjacent to the Changjiang River and Chjudo Island. 5. Marine Biology - The distribution of the concentration of chlorophyll $a$ and the estimation of the primary production. J Shandong Coll Oceanol 16:1-6

Chau YK, Abesser R (1958) A preliminary study of the hydrology of Hong Kong territorial waters. Hong Kong Univ Fish J 2:37-42

Chau YK, Wong CS (1960) Oceanographic investigations in the northern region of the South China sea off Hong Kong Hong Kong Univ Fish J 3:1-25

Chervin MB, Malone TG, Neale PJ (1981) Interactions between suspended organic matter and copepod grazing in the plume of the Hudson River. Estuar Coast Shelf Sci 13: $169-183$

Cloern JE (1996) Phytoplankton bloom dynamics in coastal ecosystems: a review with some general lessons from sustained investigation of San Francisco Bay, California. Rev Geophys 34:127-1.68

Cloern JE, Cole BE, Wong RLJ, Alpine AE (1985) Temporal dynamics of estuarine phytoplankton: a case study of San Francisco Bay. Hydrobiologia 129:153-176

Collos Y, Souchu P, Treguer P (1989) Relationships between different forms of inorganic nitrogen in rainwater of a coastal area and ground level gaseous nitrogen oxides. Atmos Res 23:97-104

Crump BC, Baross JA (1996) Particle-attached bacteria and heterotrophic plankton associated with the Columbia River estuarine turbidity maxima. Mar Ecol Prog Ser 138: 265-273

de Lafontaine Y, Demers S, Runge J (1991) Pelagic food web interactions and productivity in the Gulf of St. Lawrence: a perspective. Can Spec Publ Fish Aquat Sci 113:99-123

Dortch $Q$, Whitledge TE (1992) Does nitrogen or silicon limit phytoplankton production in the Mississippi River plume and estuary regions? Contin Shelf Res 12:1293-1309

Edmond JM, Spivack A, Grant BC, Hu MH, Chen Z, Chen S, Zeng $X$ (1985) Chemical dynamics of the Changjiang estuary. Contin Shelf Res 4:17-36

EPD (Environmental Protection Department) (1994) Marine water quality in Hong Kong for 1993. Hong Kong EPD, Hong Kong Government Printer

EPD (Environmental Protection Department) (1997) Marine water quality in Hong Kong for 1996. Hong Kong EPD, Hong Kong Government Printer

Fox LE, Lipschultz F, Kerkhof L, Wofsy S (1987) A chemical survey of the Mississippi Estuary. Estuaries 10:1-12

Gong GC, Chen YLL, Liu KK (1996) Chemical hydrography and chlorophyll a distribution in the East China Sea in summer: implications in nutrient dynamics. Contin Shelf Res 16:1561-1590

Hager SW, Gordon LI, Park PK (1968) A practical manual for 
use of the Technicon Autoanalyzer in seawater nutrient analyses. OSU Ref 68-33, Dept of Oceanogr, Oregon State University, Corvallis

Harding L, Meeson WBW, Fisher TR (1986) Phytoplankton production in two east coast estuaries: Photosynthesislight functions and patterns of carbon assimilation in Chesapeake and Delaware Bays. Estuar Coast Shelf Sci 23:773-806

Harrison PJ, Hu MH, Yang YP, Lu X (1990) Phosphate limitation in estuarine and coastal waters of China. J Exp Mar Biol Ecol 140:79-87

Hills P, Zhang L, Liu J (1998) Transboundary pollution between Guangdong Province and Hong Kong: threats to water quality of the Pearl River Estuary and their implications for environmental policy planning. J Environ Plan Manag 41:375-396

Hitchcock G, Whitledge T (1992) Nutrient/pigment variability in the Mississippi River plume and adjacent waters. In: Proceedings of Workshop, Louisiana Universities Marine Consortium, October 1991: Nutrient Enhanced Coastal Ocean Productivity. Publ. no. TAMU-SG-92-109, Texas A\&M University, College Station, p 43-51

Hong Kong Government (1995) Environment Hong Kong 1994. Hong Kong Government Printer

Hong Kong Observatory (1998) Data posted on the internet web site: http://www.info.gov.hk/hko

Hu M, Yang Y, Xu C, Harrison PJ (1990) Phosphate limitation of phytoplankton growth in the Changjiang Estuary. Acta Oceanolog Sinica 9:105-111

Kennish MJ (1986) Ecology of estuaries. Vol. I. Physical and chemical aspects. CRC Press, Boca Raton, Florida

Landry MR, Hassett RP (1982) Estimating the grazing impact of marine micro-zooplankton. Mar Biol 67:283-288

Landry MR, Kirshtein J, Constantinou J (1995) A refined dilution technique for measuring the community grazing impact of microzooplankton, with experimental tests in the central equatorial Pacific Mar Ecol Prog Ser 120: 53-63

Levasseur M, Therriault JC, Legendre L (1984) Hierarchical control of phytoplankton succession by physical factors. Mar Ecol Prog Ser 19:211-222

Lin GCS (1997) Red capitalism in south China: growth and development of the Pearl River Delta. UBC Press, Vancouver, Canada

Liss PS (1976) Conservative and non-conservative behaviour of dissolved constituents during estuarine mixing. In: Burton JD, Liss PS (eds) Estuarine chemistry. Academic Press, New York, p 93-130

Lohrenz SE, Fahnenstiel GL, Redalje DG, Lang GA, Chen X, Dagg MJ (1997) Variations in primary production of northern Gulf of Mexico continental shelf waters linked to nutrient inputs from the Mississippi River. Mar Ecol Prog Ser 155:45-54

Mackas DL, Louttit GC (1988) Aggregation of the copepod Neocalanus plumchrus at the margin of the Fraser River plume in the Strait of Georgia. Bull Mar Sci 43: $810-824$

Mallin MA, Paerl HW, Rudek J, Bates W (1993) Regulation of estuarine primary production by watershed rainfall and river flow. Mar Ecol Prog Ser 93:199-203

Malone TC (1977) Environmental regulation of phytoplankton productivity in the lower Hudson estuary. Estuar Coast Mar Sci 5:157-171

Malone TC, Chervin MB (1979) The production and fate of phytoplankton size fractions in the plume of the Hudson River, NY Bight. Limnol Oceanogr 24:683-696

Malone TC, Crocker LH, Pike SE, Wendler W (1988) influ- ences of river flow on the dynamics of phytoplankton production in a partially stratified estuary. Mar Ecol Prog Ser 48:235-249

Mann KH. Lazier JRN (1991) Dynamics of marine ecosystems: biological-physical interactions in the oceans. Blackwell Scientific Publ, London

Morton B, Wu SS (1975) The hydrology of the coastal waters of Hong Kong. Environ Res 10:319-347

Neller RJ, Lam KC (1994) The environment. In: Yeung YM, Chu DKY (eds) Guangdong: survey of a province undergoing rapid change. The Chinese University of Hong Kong Press, Hong Kong

Ning X, Vaulot D, Liu Z, Liu Z (1988) Standing stock and production of phytoplankton in the estuary of the Changjiang (Yangtse River) and the adjacent East China Sea. Mar Ecol Prog Ser 49:141-150

Paerl HW, Rudek J, Mallin MA (1990) Stimulation of phytoplankton production in coastal waters by natural rainfall inputs: nutritional and trophic implications. Mar Biol 107: $247-254$

Painchaud J, Therriault JC (1989) Relationships between bacteria, phytoplankton and particulate organic carbon in the upper St. Lawrence estuary. Mar Ecol Prog Ser 56: 301-311

Parsons TR, Maita Y, Lalli CM (1984) A manual of chemical and biological methods for seawater analysis. Pergamon Press, Oxford

Peterson DH, Smith RE, Hager SW, Harmon DD, Herndon RE, Schemel LE (1985) Interannual variability in dissolved inorganic nutrients in northern San Francisco Bay estuary. Hydrobiologia 129:37-58

Revelante N, Gilmartin M (1976) The effects of Po River discharge on phytoplankton dynamics in the northern Adriatic Sea. Mar Biol 34:259-271

Rijstenbil JW (1987) Phytoplankton composition of stagnant and tidal ecosystems in relation to salinity, nutrients, light and turbulence. Neth J Sea Res 21:113-123

Rijstenbil JW (1988) Selection of phytoplankton species in culture by gradual salinity changes. Neth I Sea Res 22 $291-300$

Ruddle K, Zhong G (1988) Integrated agriculture-aquaculture in South China: the dike-pond system of the Zhujiang Delta. Cambridge University Press, Cambridge, UK

Schlüter L (1998) The influence of nutrient addition on growth rates of phytoplankton groups, and microzooplankton grazing rates in a mesocosm experiment. J Exp Mar Biol Ecol 228:53-71

Shen $Z$ (1993) A study on the relationships of the nutrients near the Changjiang River estuary with the flow of the Changjiang River water. Chin J Oceanol Limnol 11: $260-284$

Sinclair M (1978) Summer phytoplankton variability in the lower St. Lawrence estuary. J Fish Res Board Can 35: $1171-1185$

Slawyk G, Maclsaac JJ (1972) Comparison of two automated ammonium methods in a region of codstal upwelling. Deep-Sea Res 19:521-524

Soto Y, Bianchi M, Martinez J, Rego JV (1993) Seasonal evolution of microplanktonic communities in the estuarine front ecosystem of the Rhone River plume (north-western Mediterranean Sea). Estuar Coast Shelf Sci 37:1-13

Therriault JC, Levasseur M (1985) Contral of phytoplankton production in the lower St. Lawrence Estuary: light and freshwater runoff. Nat Can (Que) 112:77-96

Turner RE, Rabalais NN, Zhang Z (1987) Plankton dynamics in the Yellow River plume. EOS 68:1735

Watts JCD (1971a) The hydrology of the continental shelf 
area south of Hong Kong. 1 Oceanographic observation for the year 1969. Hong Kong Fish Bull 2:51-57

Watts JCD (1971b) A general review of the oceanography of the northern sector of the South China Sea. Hong Kong Fish Bull 2:41-50

Watts JCD (1973) Further observation on the hydrology of the Hong Kong territorial waters. Hong Kong Fish Bull 3:9-35

Williamson GR (1970) The hydrography and weather of the Hong Kong fishing grounds. Hong Kong Fish Bull 1:43-49

Wood ED, Armstrong FAJ, Richards FA (1967) Determination of nitrate in seawater by cadmium-copper reduction to nitrite. J Mar Biol Assoc UK 47:23-31

Yin K, Harrison PJ, Pond S, Beamish RJ (1995a) Entrainment of nitrate in the Fraser River plume and its biological implications. 1. Effects of salt wedge. Estuar Coast Shelf Sci 40:505-528

Yin K, Harrison PJ, Pond S, Beamish RJ (1995b) Entrainment of nitrate in the Fraser River plume and its biological implications. II Effects of spring vs neap tides and river discharge. Estuar Coast Shelf Sci 40:529-544

Yin K, Harrison PJ, Pond S, Beamish RJ (1995c) Entrainment of nitrate in the Fraser River plume and its biological

Editorial responsibility: Otto Kinne (Editor), Oldendorf/Luhe, Germany implications. III. Effects of winds. Estuar Coast Shelf Sci 40:545-558

Yin K, Harrison PJ, Goldblatt RH, Beamish RJ (1996) Spring bloom in the central Strait of Georgia: Interactions of river discharge, winds and grazing. Mar Ecol Prog Ser 138: $255-263$

Yin K, Harrison PJ, St. John MA, Beamish RJ (1997a) Effects of a fluctuation in Fraser River discharge on primary production in the central Strait of Georgia, British Columbia, Canada. Can J Fish Aquat Sci 54:1015-1024

Yin $\mathrm{K}$, Goldblatt RH, Harrison PJ, Clifford PJ, St. John MA, Beamish RJ (1997b) Importance of wind and river discharge in influencing nutrient dynamics and phytoplankton production in summer in the Central Strait of Georgia. Mar Ecol Prog Ser 161:173-183

Yin K, Harrison PJ, Goldblatt RH, Beamish RJ (1997c) Factors controlling the timing of the spring bloom in the Strait of Georgia estuary. Can J Fish Aquat Sci 54:1985-1995

Zar JH (1984) Biostatistical analysis, 2nd edn. Prentice-Hall, Engelwood Cliffs, $\mathrm{NJ}$

Zhao H (1990) Evolution of the Pearl River Estuary. Ocean Press, Beijing, China (in Chinese)

Submitted: January 25, 1999; Accepted: October 15, 1999

Proofs received from author(s): February 21, 2000 